\title{
Study of The Effect of Bisphenol A and Anise Oil on Some Sexual Hormones in Male Albino Rats and Illustration of The Effects of Aphanizomenon Flos-Aquae on Their Actions
}

Eman G.E. Helal ${ }^{1}$, Mohamed A. Abdelaziz ${ }^{2}$, Hewaida A.E. Fadel ${ }^{3}$, Abeer Zakaria ${ }^{1}$

${ }^{1}$ Zoology Department, Faculty of Science (Girls), Al-Azhar University, ${ }^{2}$ Physiology Department, Faculty of Medicine, Al-Azhar university, ${ }^{3}$ Department of Nutritional Chemistry\& Metabolism,

National Nutrition Institute, Cairo, Egypt

*Corresponding Author: Eman G.E. Helal, E-mail: emanhelal@ hotmail.com, Mobile: 00201001025364, Orchid.org/0000-0003-0527-7028

\begin{abstract}
Background: Xenoestrogens are compounds like estrogens in effect but not in structure which are mimicking the action of endogenous estrogen and activate estrogen receptor. Phytoestrogens are naturally occurring non-steroidal plant chemicals that can act like the female hormone estrogen. Aphanizomenon Flos-aquae (AFA) is a blue-green microalgal species which has antioxidant properties.

Objective: The aim of the study was to clarify the effects of both Bisphenol A (BPA) and anise oil (phytoestrogen) together on some sexual hormonal pattern in male albino rats and illustration of the adverse effects of AFA on their actions.

Materials and methods: Thirty male albino rats were used. They were divided into three groups: Group I: control (untreated group), Group II: rats treated with BPA and Anise oil and Group III: rats treated with BPA and Anise oil in addition to AFA. Blood samples were collected for different biochemical investigations.

Results: The biochemical results showed highly significant increase $(\mathrm{p}<0.01)$ in the activities of ALT, AST, urea, creatinine, FSH, prolactin and lipid profile (total cholesterol, triglycerides, HDL-C, VLDL, LDL/HDL \& TC/HDL). While, there was a highly significant decrease $(\mathrm{p}<0.01)$ in LDL-C, total protein, albumin, Globulin, testosterone and LH. These results returned back to the normal values after receiving the AFA as compared to normal group.

Conclusion: It could be concluded that phytoestrogen and xenoestrogen have undesirable effects and it is recommended to minimize the utilization of these compounds to protect people from its hazardous effects.
\end{abstract}

Keywords: BPA, Anise oil, AFA, Hormonal assay, Biochemical parameters.

\section{INTRODUCTION}

Xenoestrogens are small lipophilic molecules that mimic physiological estrogens ${ }^{(\mathbf{1})}$ and linked to a variety of disease states even when present at concentrations far below those currently allowed by federal regulations (2). Bisphenol A (BPA) is an estrogenic chemical able to interact with human estrogen receptors (ER). Many lines of evidence reveal that BPA has an impact as an endocrine disruptor even at low doses. Bisphenol- A (BPA) is a chemical used for lining metal cans and in polycarbonate plastics, such as baby bottles. In rodents, BPA is associated with early sexual maturation, altered behavior and effects on prostate and mammary glands. In humans, BPA is associated with cardiovascular disease, diabetes and male sexual dysfunction in exposed workers. Food is a major exposure source.

BPA can contaminate the environment in significant amounts by leaching from products (plastic food containers and water containers, dental sealants and some cash register receipts) and as byproducts of manufacturing ${ }^{(3)}$. The herbs chosen for this study, contain phytoestrogens as shown from their chemical constituents. Anise or Aniseed is a flowering plant in the family Apiaceae. It is used extensively as a spiceand is listed by the Council of Europe as a natural source of food flavoring. It is stated to possess expectorant, antispasmodic, carminative, and parasiticide properties (4). The seeds of anise contain 1.5-6\% essential oil, 10-
$20 \%$ fixed oil and $18 \%$ protein. The main constituents of the essential oil are $90 \%$ anethole, $2-4 \%$ gammahimachalene, < $1 \%$ p-anisaldehyde, $0.9-1.5 \%$ methylchavicol, 3\% cis-pseudoisoeugenyl 2methylbutyrate and $1.3 \%$ trans-pseudoisoeugenyl 2methylbutyrate ${ }^{(5)}$.

The main constituent of the anise oil anethole, has been considered as Anise has been reputed to increase milk secretion, promote menstruation, facilitate birth, alleviate symptoms of the male climacteric and increase libido (6). The main constituents of aniseed are coumarins, flavonoid (flavonol and flavone), glycosides, volatile oils (trans-anethole, estrgole and aniseketone), carbohydrate and lipids (saturated and unsaturated).

The most common blue green algae, Aphanizomenonflos-aquae (AFA) is commercially distributed as organic algae dietary supplements. They have significant amounts of lipid, protein, chlorophyll, carotenoids, vitamins, minerals and unique pigments. They may also have potent probiotic compounds that enhance health ${ }^{(7)}$. AFA is a fresh water unicellular blue-green algae that spontaneously grows in Upper Klamath Lake (Germany) and that is consumed as a nutrient-dense food source and for its health enhancing properties ${ }^{(8)}$. AFA is an important source of the blue 
photosynthetic pigment phycocyanin (PC), which has been shown to have potent antioxidant activity, scavenge preoxynitirite and to inhibit cyclooxygenase 2 and thus have the potential to reduce inflammation ${ }^{(9)}$. AFA is an exceptional source of carotenoids (more than 240 retinolequivalents per gram). Beta-carotene, as well as other carotenoids has been shown to be powerful antioxidants, which help in the prevention of cardiovascular diseases and cancer ${ }^{\mathbf{( 1 0 )}}$.

The aim of the study was to clarify the effect of both BPA and anise oil together on some sexual hormonal pattern in male albino rats and illustration of the adverse effect of AFA on their actions.

\section{MATERIALS AND METHODS}

30 male Albino rats of local strain weighing 110$130 \mathrm{~g}$ were used throughout the experiments. The animals were housed in isolated animal metal cages in a conditioned room at the Animal Lab of the Physiology Department, Faculty of Science, Al-Azhar University.

\section{Ethical approval}

Approval of the Ethical Committee was obtained. This study was conducted in accordance with ethical procedures and policies approved by Animal Care and Use Committee of Faculty of Medicine, AlAzhar University, Cairo, Egypt.

Animals were treated according to guidelines for the use and care of laboratory animals in temperature, ventilation, humidity and normal dark / light cycle with free access to water. The rats were fed on rodent chow diet all over the period of the work (4 weeks).

\section{Experimental design}

The rats were divided randomly into three equal groups (10 rats each).

- Group I: (control group) comprised of normal rats that maintained on standard rodent chow diet and tap water ad libitum for 30 days.

- Group II (mixture group): rats received orally anise $(1 \mathrm{ml} / \mathrm{kg}$ body weight $)$ and BPA $(20 \mathrm{mg} / \mathrm{kg}$ body weight) for 30 days.

- Group III (mixture group and AFA group): rats treated by BPA and Anise oil in addition to AFA ( $2.835 \mathrm{mg} / \mathrm{kg}$ body weight).

Body weight measurement:
Body weights were recorded before and after the experiment.

\section{Blood sample collection:}

At the end of the experiment, blood samples were collected from the retro-orbital sinus of rats after being anesthetized by ether. Serum was separated by centrifugation at $3000 \mathrm{rpm}$ for 15 minutes at room temperature to estimate biochemical parameters.

\section{Assessment of biochemical parameters:}

Serum total proteins (TP) and albumin concentration were estimated. Serum globulins concentrations were calculated according to the formula: Globulins $(\mathrm{g} / \mathrm{dl})=$ total protein $(\mathrm{g} / \mathrm{dl})-$ albumin $(\mathrm{g} / \mathrm{dl})$. The ratio of serum albumin/ globulin was determined. Aspartate aminotransferase (AST), alanine aminotransferase (ALT) activities, creatinine, urea concentrations as well as lipid profile (cholesterol, triglycerides and high-density lipoprotein cholesterol (HDL-C) were also determined.

All parameters were estimated using Bio Merieux SA kits, France. . However, ratios of TC/HDL (risk factor 1) and LDL/HDL (risk factor 2) were also calculated after calculation of serum LDL-C (lowdensity lipoprotein cholesterol) and VLDL (very low density lipoprotein cholesterol) using the Friedwald's ${ }^{11}$ and Norbert 12 formulas respectively as follows; Friedewald's equation: LDL $(\mathrm{mg} / \mathrm{dl})=\mathrm{TC}-\{\mathrm{HDL}+$ [TG/5]\}. Norbert equation: $\mathrm{VLDL}=\mathrm{TG} / 5$.

\section{Hormonal assay}

Estimation of serum luteinizing hormone (LH), follicle-stimulating hormone (FSH) Prolactin (PRL) and testosterone $(\mathrm{T})$ were determine by using manufacture instructions of kit. All kits used for hormonal assay were from Monobind Inc., lake forest CA 92630, USA.

\section{Statistical Analysis}

The results were expressed as Mean \pm SEM. Data were analyzed by T-test and were performed using the Statistical Package (SPSS) program, version 19.The Bonferroni test was used as amethod to compare significance between groups.

\section{RESULT}

Results of the present study showed insignificant increase in the body weight in the mixture and treated group with AFA when compared to control group (Table1).

Table (1): Changes of body weight in the control and treated groups.

\begin{tabular}{|l|l|l|l|}
\hline Parameter & $\begin{array}{l}\text { Control } \\
(\text { mean } \pm \text { SE) }\end{array}$ & $\begin{array}{l}\text { Mixture } \\
(\text { mean } \pm \text { SE) }\end{array}$ & $\begin{array}{l}\text { Mixture and } \\
\text { AFA(mean } \pm \text { SE) }\end{array}$ \\
\hline $\begin{array}{l}\% \text { of body weight } \\
\text { change }\end{array}$ & $113.2 \pm 0.04$ & $\begin{array}{l}117.4 \pm 3.2 \\
3.71 \%\end{array}$ & $\begin{array}{l}116.2 \pm 3.06 \\
2.65 \%\end{array}$ \\
\hline
\end{tabular}


Values represent (mean $\pm \mathrm{SE}$ ). ( $\mathrm{P}^{*}<0.005, \mathrm{P}^{* *}<0.001$ as compared to control group).

\section{Proteins profile:}

The present study showed a highly significant decrease $(\mathrm{p}<0.01)$ in total protein, albumin and globulin in mixture group, while showed insignificant change in total protein, albumin and globulin in AFA group when compared to control group (Table 2).

Table (2): Change in protein profile in the control and treated groups

\begin{tabular}{|l|l|l|l|}
\hline Groups & Control & Mixture & $\begin{array}{l}\text { Mixture and AFA (mean } \pm \\
\text { SE) }\end{array}$ \\
\hline parameters & $($ mean $\pm \mathrm{SE})$ & $($ mean $\pm \mathrm{SE})$ & \\
\hline Total proteins $(\mathrm{g} / \mathbf{d l})$ & $6.18 \pm 0.09$ & $4.0 \pm 0.07 * *$ & $5.9 \pm 0.12$ \\
\hline \%change & & $-35.30 \%$ & $-4.50 \%$ \\
\hline Albumin $(\mathrm{g} / \mathbf{d l})$ & $3.44 \pm 0,02$ & $2.0 \pm 0.06^{* *}$ & $3.2 \pm 0.07$ \\
\hline$\%$ change & & $-41.90 \%$ & $-6.97 \%$ \\
\hline Globulin $(\mathrm{g} / \mathbf{d l})$ & $2.78 \pm 0.24$ & $2.0 \pm 0.1 * *$ & $2.7 \pm 0.03$ \\
\hline$\%$ change & & $-28.10 \%$ & $-2.90 \%$ \\
\hline Albumin/ Globulin & $1.30 \pm 0.21$ & $1.0 \pm 0.1$ & $1.2 \pm 0.02$ \\
\hline \% change & & $-23.10 \%$ & $-7.70 \%$ \\
\hline
\end{tabular}

Value represent (mean $\pm \mathrm{SE}$ ). ( $\mathrm{P}^{*}<0.005, \mathrm{P}^{* *}<0.001$ as compared to control group.

\section{Liver function tests:}

There was a highly significant increase $(\mathrm{p}<0.02)$ in the levels of ALT and AST in mixture group and nonsignificant change in the previous levels in AFA group when compared to control rats (Table 3).

Table (3): Change in liver function tests in the control and treated groups

\begin{tabular}{|c|c|c|c|}
\hline $\begin{array}{ll}\text { parameters } & \text { Groups } \\
\end{array}$ & $\begin{array}{l}\text { Control } \\
(\text { mean } \pm \text { SE) }\end{array}$ & $\begin{array}{l}\text { Mixture } \\
(\text { mean } \pm S E\end{array}$ & $\begin{array}{l}\text { Mixture and } \\
(\text { mean } \pm S E)\end{array}$ \\
\hline $\begin{array}{l}\text { ALT }(\mathrm{U} / \mathrm{dl}) \\
\% \text { change }\end{array}$ & $19.8 \pm 2.3$ & $\begin{array}{l}27.0 \pm 0.52 * * \\
36.3 \%\end{array}$ & $\begin{array}{l}23.3 \pm 0.07 \\
17.7 \%\end{array}$ \\
\hline $\begin{array}{l}\text { AST }(\mathrm{U} / \mathbf{d l}) \\
\% \text { change }\end{array}$ & $23.4 \pm 3.1$ & $\begin{array}{l}34.0 \pm 0.005^{* *} \\
45.2 \%\end{array}$ & $\begin{array}{l}28.0 \pm 0.06 \\
19.7 \%\end{array}$ \\
\hline
\end{tabular}

Value represent (mean $\pm \mathrm{SE})$. ( $\mathrm{P}^{*}<0.005, \mathrm{P}^{* *<}<0.001$ as compared to control group).

\section{Lipid profile:}

The present study showed that there was a highly significant increase $(\mathrm{p}<0.01)$ in all the parameters of lipid profile, except for HDL that showed highly significant decrease $(\mathrm{p}<0.01)$ in mixture group and showed insignificant change in AFA group when compared to control group (Table 4).

Table (4): Changes in Lipid profile in the control and treated groups

\begin{tabular}{|c|c|c|c|}
\hline parameters $\quad$ Groups & $\begin{array}{l}\text { Control } \\
(\text { mean } \pm \text { SE) }\end{array}$ & $\begin{array}{l}\text { Mixture } \\
(\text { mean } \pm \text { SE }\end{array}$ & $\begin{array}{l}\text { Mixture and AFA(mean } \\
\pm \text { SE) }\end{array}$ \\
\hline $\begin{array}{l}\text { T-C }(\mathrm{mg} / \mathrm{dl}) \\
\% \text { change }\end{array}$ & $142 \pm \mathbf{2 . 2}$ & $\begin{array}{l}175.0 \pm 0.17 * * \\
\mathbf{2 3 . 2 \%}\end{array}$ & $\begin{array}{l}148 \pm 0.9 \\
4.22 \%\end{array}$ \\
\hline $\begin{array}{l}\text { TG }(\mathrm{mg} / \mathrm{dl}) \\
\% \text { change }\end{array}$ & $82 \pm 2.6$ & $\begin{array}{l}103.0 \pm 0.17 * * \\
25.6 \%\end{array}$ & $\begin{array}{l}87 \pm 0.71 \\
16.1 \%\end{array}$ \\
\hline $\begin{array}{l}\text { HDL-C }(\mathrm{mg} / \mathrm{dl}) \\
\% \text { change }\end{array}$ & $56 \pm 1.7$ & $\begin{array}{l}42.0 \pm 0.9 * * \\
-25.0 \%\end{array}$ & $\begin{array}{l}51.0 \pm 0.005 \\
8.93 \%\end{array}$ \\
\hline $\begin{array}{l}\text { LDL-C } \\
\% \text { change }\end{array}$ & $70.6 \pm 1.8$ & $\begin{array}{l}112.4 \pm 0.14 * * \\
59.2 \%\end{array}$ & $\begin{array}{l}84.6 \pm 0.14 \\
19.83 \%\end{array}$ \\
\hline $\begin{array}{l}\text { VDL-C } \\
\% \text { change }\end{array}$ & $16.4 \pm 0.5$ & $\begin{array}{l}20.6 \pm 0.14 * * \\
25.7 \%\end{array}$ & $\begin{array}{l}17.4 \pm 0.14 \\
6.1 \%\end{array}$ \\
\hline $\begin{array}{l}\text { LDL/HDL } \\
\% \text { change }\end{array}$ & $1.27 \pm 0.04$ & $\begin{array}{l}2.7 \pm 0.06^{* *} \\
112.6 \%\end{array}$ & $\begin{array}{l}1.84 \pm 0.3 \\
44.9 \%\end{array}$ \\
\hline TC/HDL & $2.56 \pm 2.4$ & $4.2 \pm 0.07 * *$ & $3.22 \pm 0.03$ \\
\hline
\end{tabular}




\begin{tabular}{|c|c|c|c|}
\hline \multicolumn{2}{|l|}{$\%$ change } & $102.34 \%$ & $2.9 \%$ \\
\hline \multicolumn{4}{|c|}{ Value represent (mean $\pm \mathrm{SE}) .\left(\mathrm{P}^{*}<0.005, \mathrm{P}^{* *<0.001}\right.$ as compared to control group). } \\
\hline $\begin{array}{l}\text { Kidney function tests: } \\
\text { The data in table (5) showe } \\
\text { howed insignificant chang }\end{array}$ & $\begin{array}{l}\text { a highly sig } \\
\text { s in AFA gr }\end{array}$ & $\begin{array}{l}\text { rease }(0.01) \text { in } \\
\text { pared to contr }\end{array}$ & a and creatinine in $n$ \\
\hline \multicolumn{4}{|c|}{ Table (5): Change in kidney function tests in the control and treated groups } \\
\hline parameters Groups & $\begin{array}{l}\text { Control } \\
(\text { mean } \pm \text { SE) }\end{array}$ & $\begin{array}{l}\text { Mixture } \\
(\text { mean } \pm S E\end{array}$ & $\begin{array}{l}\text { mixture and AFA } \\
(\text { mean } \pm S E)\end{array}$ \\
\hline $\begin{array}{l}\text { Urea }(\mathrm{mg} / \mathbf{d l}) \\
\% \text { change }\end{array}$ & $40.2 \pm 0.9$ & $\begin{array}{l}58 \pm 1.3^{* *} \\
44.3 \%\end{array}$ & $\begin{array}{l}45 \pm 0.11 \\
11.94 \%\end{array}$ \\
\hline $\begin{array}{l}\text { Creatinine }(\mathrm{mg} / \mathbf{d l}) \\
\% \text { change }\end{array}$ & $0.5 \pm 0.2$ & $\begin{array}{l}0.7 \pm 0.07 * * \\
40 \%\end{array}$ & $\begin{array}{l}0.6 \pm 0.07 \\
20 \%\end{array}$ \\
\hline
\end{tabular}

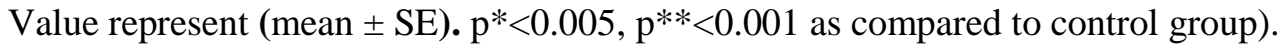

\section{Hormones:}

Results of the present study showed highly significant increase $(\mathrm{p}<0.001)$ in the level of prolactin, FSH and LH levels and highly significant decrease in testosterone level in the mixture group when compared to the normal control animal while there was insignificant changes in AFA groups when compared to control group (Table 6).

Table (6): Changes in hormonal profile in the control and treated groups

\begin{tabular}{|c|c|c|c|}
\hline parameters $\quad$ Groups & $\begin{array}{l}\text { Control } \\
(\text { mean } \pm \text { SE }\end{array}$ & $\begin{array}{l}\text { Mixture } \\
(\text { mean } \pm \text { SE }\end{array}$ & $\begin{array}{l}\text { mixture and } \text { AFA } \\
(\text { mean } \pm \mathrm{SE})\end{array}$ \\
\hline $\begin{array}{l}\text { Prolactin }(\mathrm{ng} / \mathrm{ml}) \\
\% \text { change }\end{array}$ & $4.3 \pm 0.07$ & $\begin{array}{l}\text { 6.0 } \pm 0.07 * * \\
39.5 \%\end{array}$ & $\begin{array}{l}4.8 \pm 0.06 \\
11.6 \%\end{array}$ \\
\hline $\begin{array}{l}\text { Testosterone }(\mathrm{ng} / \mathrm{ml}) \\
\% \text { change }\end{array}$ & $16.2 \pm 0.6$ & $\begin{array}{l}11.0 \pm 0.18 * * \\
-32 \%\end{array}$ & $\begin{array}{l}15.1 \pm 0.07 \\
-6.7 \%\end{array}$ \\
\hline $\begin{array}{l}\text { FSH }(\mathrm{mlu} / \mathrm{ml}) \\
\% \text { change }\end{array}$ & $2.7 \pm 0.07$ & $\begin{array}{l}3.9 \pm 0.07 * * \\
44.4 \%\end{array}$ & $\begin{array}{l}2.9 \pm 0.1 \\
7.4 \%\end{array}$ \\
\hline $\begin{array}{l}\mathbf{L H}(\mathrm{mlu} / \mathbf{m l}) \\
\% \text { change }\end{array}$ & $10.7 \pm 0.5$ & $\begin{array}{l}7.0 \pm 0.07 * * \\
-34.5 \%\end{array}$ & $\begin{array}{l}9.9 \pm 0.07 \\
-7.4 \%\end{array}$ \\
\hline
\end{tabular}

Value represent (mean $\pm \mathrm{SE})$. ( $\mathrm{P}^{*}<0.005, \mathrm{P}^{* *}<0.001$ as compared to control group).

\section{DISCUSSION}

Environmental estrogens (xenoestrogens) are a diverse group of chemicals that mimic estrogenic actions and may have adverse effects on human health. Many xenoestrogens can access the human body by ingestion or absorption through the skin and mucosal membranes ${ }^{(\mathbf{1 3})}$. In this work, three compounds are tested: bisphenol A (monomer of polycarbonate plastics), anise oil and AFA.

\section{Liver functions}

In the present study the increased activities of AST and ALT in mixture group may be due to hepatotoxicity and liver damage, as the more severe the liver damages the higher the release of the liver enzymes. Serum levels of transaminases were used as an indicator of damage to the liver structural integrity because these enzymes are cytoplasmic in location and are released into the circulating blood only after structural damage (14). The mixture had estrogen mimetic activity and cytotoxic effect. The metabolites of its toxicity (isopropyl hydroxyphenol) were produce by the cleavage of BPA glutathione conjugate, gluathionly-

phenol, gluathionycl4- isopropylphenol and BPA dimmer. The hepatocytes of rats had strong capability for glucouronidation of BPA in the liver and not to transport, accumulate or generate toxic and carcinogenic substance ${ }^{(\mathbf{1 5})}$.

Hirokilnoue et al. ${ }^{(16)}$ demonstrated that toxic substances, which are generated from BPA and accumulated in liver can induce toxicity in the liver. However, BPA glucuronide was excreted with bile where the glucuronide was absorbed and transported in great amounts into the serosal side of the colon. The large amount of BPA glucuronide excreted into the intestinal tract would also be absorbed into the colon. Also, some of the conjugated BPA is catalyzed by the lumenal bacteria into B-glucuronidase, meanwhile BPA would eventually be reabsorbed into the intestine 
(17). Also anise has toxic effect on the liver where it contain coumarins, which has toxic effect on the liver (18).

AST and ALT elevation was reduced in the animals treated with AFA to a value close to the normal. This might be due to the antioxidant activity of some AFA constituents that exhibited a hepatoprotective effect against liver damage ${ }^{(\mathbf{1 9})}$.

\section{Proteins profile}

In the present study, the mixture of bisphenol A and anise oil caused toxicity and inflammation of liver, which induced significant decrease in protein profile. Decreased levels of total serum proteins might be due to deactivation of protein disulfide isomerase, a multifunctional protein critically involved in the folding and shedding of cellular proteins ${ }^{(20)}$.

The decreased protein levels could be related to damage of cells caused by BPA. The decrease in protein content under stress induced by BPA may be attributed to the utilization of amino acids in various catabolic reactions. BPA may either act by activating or inhibiting enzyme activities in the cell or destruction of the cell organelles with liberation of particular enzymes, which is one of the reasons to alter the expression of total proteins. Another reason is oxidative stress influenced by excess reactive oxygen species (ROS) produced in mitochondria and microsomes in cells, which are known to damage proteins. BPA-induced oxidative stress in mitochondria and microsomes of cells are known to damage proteins. This can lead to various diseases, including cancer, infertility and neurodegenerative diseases ${ }^{(\mathbf{2 1})}$.

Proteins are found in all cells of the body as well as in all fluids ${ }^{(22)}$. The hypoproteinemia observed in the present results revealed the hepatotoxic nature of BPA on liver cells.

The synthesis of albumin is depressed in a variety of diseases particularly those of the liver. One of the gradients of anise $D$-Limonene is a naturally cyclic terpene and a major component of several plant essential oils. It causes decrease in protein as a result of increase excretion in urine. Meanwhile, after treating by AFA a significant improvement in the protein profile and its level was elevated to the normal. This is because Aphanizomenon flos-aquae contains more protein than any other organism (plant or animal). Blue-green algae (AFA) contain a wide range of antioxidants in the form of specific trace minerals, amino acids, vitamins, pigments, variety of carotenes along with phycocyanin and chlorophyll, which protects the cells from free radicals damage. C-phycocyanin (CPC), which constitute up to $15 \%$ of the dry weight of a blue green algae contributes to the antioxidant, anti-inflammatory, neuroprotective and hepatoprotective effect that protect the body against the oxidative stress and free radical damages ${ }^{(23)}$.

\section{Lipid profile}

In the present study, the mixture of bisphenol-A and anise oil caused a highly significant increase of all the parameters of lipid profile, except HDL-C level, which showed a highly significant decrease in comparison with control group. These compounds can induce estrogenic activity where estrogens have a significant effect on plasma cholesterol. The effect on cholesterol is probably due to an action of the hormone on the lipoproteins associated with cholesterol in the circulation. The higher estrogen like effect of BPA may be the reason for the incidence of myocardial infarction and other complications of arteriosclerotic vascular diseases. The liver has a complex network of nuclear receptors that coordinately regulate the expression of enzymes involved in lipid metabolism from fatty acid oxidation and uptake to triacylglycerol synthesis, accumulation and secretion ${ }^{(24)}$.

BPA has also found to stimulate lipid accumulation and up-regulate genes involved in lipid metabolism in adipocytes (25). Mechanistically, environmental BPA is a well-known endocrinedisrupting chemical that binds to estrogen receptors (ER alpha and ER beta) and results in competition with estrogen disrupting the lipid profile. BPA-induced oxidative stress is associated with excess reactive oxygen species (ROS) production that are known to alter lipid profile activity.

Meanwhile, treating with AFA, improved lipid profile as compared to the mixture-treated animals ${ }^{(26)}$. Blue green algae (BGA) inhibits intestinal cholesterol absorption, decreases hepatic lipids and leads to attenuation of plasma total cholesterol and triglyceride concentrations. BGA can also decrease oxidative stress due to their free radical scavenging activity and inhibition of lipid per-oxidation, which act as hypolipidemic ${ }^{(27)}$.

\section{Kidney functions}

In the present study, the mixture of bisphenol A and anise oil caused increase in the level of urea and creatinine that might indicate renal insufficiency, nephritis, renal function impairment and urinary tract obstruction. Urea is formed in the liver and represent the major end product of proteins catabolism and is excreted by the kidney. Vries $\boldsymbol{e t}$ al. ${ }^{(28)}$ recorded a reduced rate of renal clearance of 1-naphthol-beta-D glucuronide in BPA glucuronide, which was also excreted into the urine through the kidney. But in anise oil oral administration to $d$-Limonene would completely be absorbed in gastrointestinal tracts of both humans and animals then rapidly distributed to various tissues, including kidney and liver. Some reports showed that $d$-Limonene increases the chance of hyperplasia and adenocarcinoma in rat kidney. Furthermore, other studies ${ }^{(29)}$ demonstrated that $d$ - 
Limonene causes spontaneous nephropathy. Normal male rats of 30 days old exhibited marked increased protein excretion in the urine.

$D$-limonene, which is recognized as an experimental carcinogen because it causes nephropathy and kidney tumors in male rats, that results from binding to a2u-globulin in the kidney ${ }^{\left({ }^{30)}\right.}$. Coumarin compounds are another high component of anise, It is toxic when concentrated due to internal hemorrhage and kidney toxicity. Also, coumarins are the carcinogen in rats causing adenomas of the kidney.

Meanwhile, treating with AFA, recorded an improvement in the kidney function to the normal level this may be due to its antioxidant properties The renoprotective effect of AFA may be due to the presence of phycocyanin pigment that has been suggested to act as an antioxidant and exert its antioxidant activity by scavenging lipid peroxidation that improved renal functions via attenuating an oxidative stress-mediated decline in GFR and renal hemodynamics ${ }^{(31)}$.

\section{Hormones}

There was a highly significant increase in FSH and prolactin hormones level of the rats of the mixture group as compared to the control group. BPA caused hyperprolactinemia, which was progressively increased with time of the experiment that reached 30 days. Similar data were obtained by Rosemary et al. ${ }^{\left({ }^{(32)}\right.}$ who stated that BPA had estrogen-like effect mimicked estradiol in inducing hyperprolactinemia in an estrogen-sensitive rat. The mechanism may indicate that BPA can induce hyperprolactinemia, which alter estrogen receptor and/or estrogen-responsive genes that affect the lactotrophs in rats ${ }^{(33)}$.

Also, Bo Lü ${ }^{(34)}$ showed that the blood serum hormone levels of parental female rats were altered by BPA exposure. The PRL and E2 levels of blood serum of BPA group were markedly increased. BPA may simulate estrogen to increase the level of serum PRL, because estrogen has a direct role in stimulating PRL gene expression. In the present study, it was found that BPA induced a significant elevation in FSH with concomitant reduction in LH levels with the two dose levels used. Differences in the response of FSH and LH to BPA could be due to differential sensitivity of the systems regulating FSH \& LH secretion to BPA at the level of the pituitary or the hypothalamus.

However, Funabashi et al. ${ }^{(35)}$ suggested that BPA could have hypothalamic actions and can alter levels of progesterone receptor expression within the mediobasal hypothalamus. These induced changes in neural systems that could impact upon gonadotrophin secretion.

The present data revealed that serum testosterone level recorded a significant decrease after treatment with BPA. This is in agreement with the results of
Benson et al. ${ }^{(35)}$ where they reported that BPA had adverse effects on testicular function by decreasing pituitary LH secretion and reducing Leydig cells steroidogenesis. So, BPA suppressed T production via decreased LH secretion. There is also evidence that BPA interferes with LH receptor-legend binding. Rats treated with anise oil had several histopathologic changes in Sertoli and Leydig cells. The destructive effect of anise oil may be related to its safrole content. Safrole has been associated with the presence of safrole-DNA adduct in human. Zhou et al. ${ }^{(35)}$ reported that some safrole (and other naturally occurring alkenylbenzenes) can undergo metabolic activation by sequential 1-hydroxylation and sulfation, resulting in reactive intermediates capable of forming DNA adducts and finally genotoxicity. A high phytoestrogen diet in male rats can also block spermatogenesis, induce germ cell apoptosis and decrease the expression of ER $\alpha$ and $\mathrm{AR}$ in the cauda epididymis as well as increase lipoperoxidation in epididymal sperm. These effects are possibly mediated by disruption of the steroid regulation of the epididymis, resulting in decreased quality of sperm, and thereby reducing fecundity ${ }^{(35)}$.

\section{CONCLUSION}

It could be concluded that phytoestrogen and xenoestrogen have undesirable effects and it is recommended to minimize the utilization of these compounds to protect people from its hazardous effects.

\section{REFERENCE}

1. Watson CS, Jeng YJ, Kochukov MY (2010): Nongenomic signaling pathways of estrogen toxicity. Toxicol Sci ., 115: 1-11.

2. Alonso MP, Laribi O, Ropero AB et al. (2005): Low doses of bisphenol- A and diethylstilbestrol impair $\mathrm{Ca} 2+$ signals in pancreatic alpha-cells through a nonclassical membrane oestrogen receptor within intact islets of Langerhans. Environ Health Perspect., 113: 969-977.

3. Schecter A, Malik N, Haffner D et al. (2010): Bisphenol A (BPA) in US food. Environ. Sci Technol., 44 (24): 9425-9430.

4. Chevallier A (1996): Encyclopedia of medical plants, New York,NY: DK publishing; Pp: 246-47.

5. Rodrigues V M, Rosa P T, Meireles M A et al. (2003): Supercritical extraction of essential oil from aniseed (Pimpinellaanisum L.) using CO2: solubility, kinetics and composition data. J Agric Food Chem., 51 (6): 1518-1523.

6. Bancroft $\mathbf{J}$ (1982): Theory and practice of histoplogical techniques. Bancroft JD and Stevens A (eds.) . 2nd edition . Churchilll Living stone, London, Pp: 3790-405.

7. Singh S, Kate BN, Banerjee UC (2005): Bioactive compounds from cyanobacteria and microalgae: An overview. Crit Rev Biotechnol., 25: 73-95.

8. Pugh N, Pasco DS (2001): Characterization ofhuman monocyte activation by a water soluble preparationof Aphanizomenon flos-aquae. Phytomed., 8: 445-453. 
9. Li Y J, Han Z, Ge L et al. (2016): Cphycocyaninprotects against low fertility by inhibitingreactive oxygen species in aging mice. Oncotarget, doi: 10.18632/oncotarget.8165.

10.Khuantrairong T, Traichaiyaporn S (2012).Enhancement of carotenoid and chlorophyll content of anedible freshwater alga (Kai: Cladophora sp.) by supplementaryinorganicphosphate and investigation of its biomassproduction. Maejo Int J Sci Technol., 6(01): 111.

11. Friedwald's WT, Levy RI, Fredrickson DS et al. (1999): Estimation of the concentration of low-density lipoprotein cholesterol in plasma, without use of the preparative ultracentrifuge. Clin Chem., 18: 499-502.

12. Norbert WT (1995): Clinical guide to laboratory tested.3rd ed.saunders W.B. company, philadephi. https://onlinelibrary.wiley.com/doi/abs/10.1111/j.15372995.1995.tb03571.

13. Korach KS (1993): Editorials uprising places of estrogenic activity. Endocrinology, 132: 2277-2278.

14.Segre EJ (1975): Naproxen metabolism in man. J Clin Pharmacol., 15: 31-39.

15.Jaeg JP, Perdu E, Dolol DL et al. (2004): Characterization of new Bisphenol-A metabolites produced by CDI mice liver microsome and 59 fractions. American Chemical Society, 15: 2638. 2645.

16. Hirokilnoue, Hiroshi Y, Tsunehisa M et al. (2001): Bisphenol-A Glucuronide, a Major Metabolite in rat bile after liver perfusion. Drug Metabolism and Disposition, 29: 1084-1087.

17. Inoue H, Yokota H, Taniyama H et al. (1999): 1Naphthol B-D-glucuronide formed interaluminally in rat small intestine mucosa and absorbed into the colon. Life Sci., 65: 1579-1588.

18.Stansbury J (2016): Medical Clinic Apothecary Natural Goods. Retrieved 11 5, 2016, from http:// www. battlegroundhealingarts.com/articles/the apiaceaefamilymedicinal-plant-research-summary/.

19. Elmalawany A, Tarek A, Salem T (2014): Effect of blue green algae on some biochemical and hematological markers in mice. International Journal of Advanced Research, 2 (2): 568-574.

20.Hiroi T, Okada K, Imaoka S, Osada M, Funae Y (2006): Bisphenol A binds to protein disulfide isomerase and inhibits its enzymatic and hormone binding activities. Endocrinology, 147 (6): 2773 - 80.

21.Zhang X, Chen, CH, Confino E et al. (2005): Increased endometrial thickness is associated with improved treatment outcome for selected patients undergoing in vitro fertilization-embryo transfer. Fertility and Sterility, 83: 336-340.

22. Lappas CM, Lappas NT (2012): D-Limonene modulates T lymphocyte activity and viability. Cell Immunol., 279: 30-41.

23. Logothetopoulos J, Weinbren $K$ (1955): Naturally occurring protein droplets in the proximal tubule of the rat's kidney. British J Experiment Pathol., 36: 402-406.
24. Scoglio S, Benedetti Y, Benvenuti F, Battistelli S (2014): Selective monoamine oxidase Binhibition byan Aphanizomenon flos-aquae extract and byits constitutive active principles phycocyanin andmycosporine-like amino acids. Phytomed., 21 (7): 992-997.

25. Nguyen P, Leray V, Diez M, Serisier S et al. (2008): Liver lipid metabolism. J Anim Physiol Anim Nutr., 92: 272-283.

26. Masuno H, Kidani T, Sekiya K, Sakayama K et al. (2002): Bisphenol A in combination with insulin can accelerate the conversion of 3T3-L1 fibroblasts to adipocytes. J Lipid Res., 43: 676-684.

27. Helal EG, El-Sayed RA, Mostafa-Hedeab G et al. (2017): The Therapeutic Effects of Stem Cell Enhancer on Changes of Some Physiological Parameters in Male Albino Rats Treated With Mixture of Food Additives) Food Preservative, Food Coloring Agent, and Flavor Enhancer). Egyptian Journal of Hospital Medicine, 67 (2): 591-598.

28. Vries MH, Redegeld FA, Koster AS et al. (1989): Hepatic, intestinal and renal transport of 1-naphthol-B-Dglucuronide in utant rats with hereditary-conjugated hyperbillirubinemia. Naunyn-schmiedebergs Arch Pharmacol., 340:588-59

29. Crowell PL, Lin S, Vedejs E, Gould M N (1992): Identification of metabolites of the antitumor agent dlimonene capable of inhibiting protein isoprenylation and cell growth. Cancer Chemother Pharmacol J., 31: 205212.

30.Stansbury J (2016): Medical Clinic Apothecary Natural Goods. Retrieved 11 5, 2016, from http:// www. battleground healingarts.com/articles/the apiaceaefamilymedicinal-plant-research-summary/.

31. Kuriakose G (2008): Evaluation of Renoprotective Effect of Aphanizomenon flos-aquae on Cisplatin-Induced Renal Dysfunction in Rats. Renal Failure, 30: 717-725.

32. Rosemary, Steinmetz, Nancy G et al. (1997): The environmental estrogen Bisphenol-A stimulates prolactin release in vivo and in vitro. Endocrinology, 138: 17801786

33. Kuiper GG, Carlsson B, Grandien K et al. (1998): Comparison of the legend binding specificity and transcript tissue distribution of estrogen receptors alpha and beta. Endocrinology, 138 (3): 863-870.

34. Bo Lü, Zhan P (2010): The effects of bisphenol A on sex hormone levels of F0 female rats and F1 male rats during weaning period. Toxicological and Environmental Chemistry, 92: 1729-1733.

35. Funabashi T, Sano A, Mitsushima D, Kimura F (2003): Bisphenol-A increases progesterone receptor immunoreactivity in the hypothalamus in a dose dependent manner and affects sexual behavior in adult ovaricectomised rats. J Neuroendocrinol., 15: 134-140. 